Brit. J. industr. Med., 1959, 16, 290.

\title{
STUDIES ON THE NATURE AND AETIOLOGY OF RESPIRATORY DISABILITY IN WITWATERSRAND GOLD-MINERS FREE OF RADIOLOGICAL SILICOSIS
}

\author{
BY \\ MARGARET R. BECKLAKE,* SAUL ZWI, $\uparrow$ and W. LUTZ \\ From the Pneumoconiosis Research Unit, Council for Scientific and Industrial Research, and the \\ Pneumoconiosis Bureau, Johannesburg, South Africa
}

(RECEIVED FOR PUBLICATION JANUARY 26, 1959)

\begin{abstract}
In an investigation into the cause of symptoms in gold-miners who have no radiological silicosis, the relationship of dyspnoea and physiological disturbances to dust exposure was examined. Forty-five subjects, aged 41 to 45 years, with normal chest radiographs and long service underground were chosen for study from the population of miners past and present. Thirty-four men only were tested, but the validity of the sample was checked by comparison with a similar group of miners reported previously.

Each individual's dust exposure was estimated in "particle-hours". A detailed history, including smoking habits, was followed by a clinical examination and a battery of lung function tests in each case.

No significant relationship was found between dyspnoea and dust exposure or smoking. However, a negative correlation was observed between dust exposure and effort tests, implying that exercise capacity appeared best in those men whose dust exposure was greatest. Possible reasons for this finding are discussed.

On the other hand, dyspnoea did correlate with airway obstruction and hyperventilation on effort, indicating a physiological rather than a psychological basis for the symptoms. Further, the higher incidence of cough, sputum, and rhonchi in the more disabled subjects suggested that chronic bronchitis might be the basis of their symptoms, but the cause of the bronchitis remains to be identified. It seems that dust exposure alone was not the cause, but the findings do not exclude the possibility of its being related to the occupation of mining with stresses such as inhalation of fumes and rapid changes in temperature, humidity, and altitude.
\end{abstract}

In recent years medical men concerned with the health of miners have become increasingly aware of the poor correlation between the degree of disability of the miner and the radiological evidence of pneumoconiosis (Pemberton, 1956; Newell and Browne, 1955). In the case of the Witwatersrand gold-miner interest has centred on those miners who are obviously disabled but whose chest radiograph shows no signs of dust disease. There appear to be three possible causes of disability (or any combination of these) in such a miner:-

(1) Psychogenic factors producing exaggeration of symptoms (including malingering);

*Present address: McGill University Clinic, Royal Victoria Hospital, Montreal 2, Quebec.

†Present address: Department of Medicine, Witwatersrand University Medical School, Johannesburg.
(2) Presence of other lung disease, e.g., bronchitis, bronchospasm, or emphysema;

(3) Presence of dust fibrosis as yet radiologically undetectable.

Undoubtedly a small number of men fall into the first group. However, a study of the lung function of Witwatersrand gold-miners selected at random on radiological grounds left about $30 \%$ of the subjects studied unassigned to either the normal or abnormal lung function classes (Becklake, du Preez, and Lutz, 1958). Investigation of this ambiguous group obviously required study of the second and third possibilities listed above.

In a previous investigation comparing radiologically normal miners with railway workers (Zwi and Becklake, 1958), the incidence of bronchitis and emphysema (using the criteria of Pemberton, 1956) 
was found to be no different in the two groups. Consistent differences in the lung function tests of the two groups were not found, though maximum voluntary ventilation was reduced and non-elastic resistance increased in the miners.

The present study was designed to investigate the third possible cause of disability in these radiologically normal miners by studying the relation of symptoms and physiological disturbances to the duration and severity of dust exposure.

\section{Methods}

The cases required for study in the present series were thus miners of similar age with no radiological signs of pneumoconiosis (cases with increased lung markings were also excluded), but among whom there was considerable variation in the amount of dust exposure. Length of service on rock-breaking jobs provided the index of dust exposure on which the men were selected.

An annual examination (clinical and radiological) at the Pneumoconiosis Bureau, Johannesburg, is compulsory for all working miners, for all retired miners who wish to retain the right to mine, and all men in receipt of partial compensation for dust disease until such time as they are in receipt of maximum compensation. From the Bureau records of men examined between December, 1955, and May, 1956, a list was compiled of all men between 41 and 45 years of age whose chest radiographs were considered normal. These cases were then sorted according to the record of rock-breaking service, and 45 men were selected at random from those available. The radiographs were read independently by three observers; only those agreed as normal by all three were accepted, and they were then checked against the reading of the man's previous radiograph. Thirty-four men were finally tested (Table 1A), none of whom had mixed service, i.e., their mining experience was restricted to goldmining.

TABLE 1A

THE PLAN OF THE STUDY

\begin{tabular}{c|c|c}
\hline $\begin{array}{c}\text { Claimed } \\
\text { Rock-breaking } \\
\text { Service } \\
\text { (years) }\end{array}$ & $\begin{array}{c}\text { Number of Men } \\
\text { Selected }\end{array}$ & $\begin{array}{c}\text { Number of Men } \\
\text { Tested }\end{array}$ \\
\hline$<1$ & 9 cases (254) & 4 cases \\
5 to $5 \frac{1}{2}$ & 9 cases (22) & 6 cases \\
11 to $11 \frac{1}{2}$ & 9 cases (10) & $\begin{array}{l}6 \text { cases } \\
14 \text { to } 14 \frac{1}{2}\end{array}$ \\
17 to $17 \frac{1}{2}$ & 9 cases (16) \\
\hline Total & 45 cases $(12)$ & 9 cases \\
\hline
\end{tabular}

The number in parentheses is the total number of cases in the particular population from which the sample was drawn at random.

Cases were rejected for the following reasons:-Three would not cooperate, two had moved to distances over 250 miles from Johannesburg, one had severe complicating angina pectoris, one a disabling back injury, and one could not be traced; in one, service records could not be accurately computed because he had served in a mine where the records before 1942 had been destroyed by fire, and two had worked at a Government miners' training school where no accurate service records were kept.

Since the Bureau records of a miner's service were based on the miner's own statements and were generally considered inaccurate, service records of each man were then checked against those held by the Chamber of Mines for number of shifts worked underground and number of shifts on rock breaking. These can be considered accurate since it was on these records that the man's pay was based, rock breaking being more highly paid than other underground work. In some instances the difference between the miner's statement of his service on rock breaking and that of the Chamber of Mines was considerable. Unfortunately, the accurate assessment of shifts worked in rock-breaking jobs could not be made before selection for study, so the number of subjects tested in each group of rock-breaking service was not as evenly distributed as was planned (Table 1B).

TABLE 1B

TESTED CASES GROUPED ACCORDING TO CONFIRMED ROCK-BREAKING SERVICE

\begin{tabular}{c|c}
\hline $\begin{array}{c}\text { Confirmed } \\
\text { Rock-breaking Service } \\
\text { (shifts) }\end{array}$ & Number of Men Tested \\
\hline 0 to 999 & 6 cases \\
1,000 to 1.999 & 4 cases \\
2000 to 2,999 & 6 cases \\
3,000 to 3,999 & 9 cases \\
4,000 to 4,999 & 5 cases \\
5,000 or more & 4 cases \\
\hline Total & 34 cases \\
\hline
\end{tabular}

A more accurate estimate of the dust exposure of each man was attempted using information provided by $\mathrm{Mr}$. R. S. J. du Toit, of the Government Mining Engineer's Office, which has published records of konimeter counts in all scheduled mines since 1931. It was calculated in "particle-hours", the product of the hours of a man's underground service and average konimeter count* in scheduled mines for the particular years of his service. Fig. 1 (reproduced from du Toit, 1958) shows average levels of dustiness in different parts of mines for each year from 1931 to 1955 .

A careful clinical history was taken in each case with emphasis on respiratory symptoms and details of smoking habits. A man was considered a smoker if he had smoked regularly for one year; the number of cigarettes was noted in tens, e.g., one to 10 noted as 10,11 to 20 as 20. One ounce of pipe tobacco per week was considered equal to four cigarettes a day (Doll and Hill, 1950). Dyspnoea was graded on the scale suggested by Fletcher (1952). A full clinical examination was carried out on each subject by one of us. In addition the records of previous annual examinations at the Pneumoconiosis Bureau were reviewed to note the number of occasions on which rhonchi had been reported. The average age of the group was 44 years, and recruits must be 17 years of age to start underground work, so that 27 annual examinations would be the maximum number expected for men of this

* Konimeter count represents incombustible, acid-insoluble particles at a magnification of $\times 150$ under dark field illumination. 


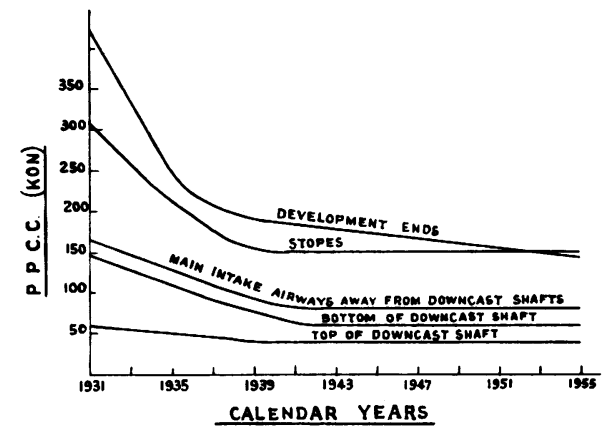

Fig. 1.-The curves are based on the results recorded by government inspectors of mines during routine inspections. Allowance has been made for the altered techniques introduced after 1931. The konimeter counts (in particles $/ \mathrm{ml}$.) include particles ranging in size from about 0.3 to $5 \mu$. About $30 \%$ of the count is constituted by particles from 1 to $5 \mu$.

age. However, between 30 and 40 records were available for most cases, indicating that many men had undergone several extra examinations during their mining careers, presumably because of complaints about their health.

Lung function tests were carried out using the methods previously described by Becklake and others (1958). Measurements of lung volume, maximum voluntary ventilation (M.V.V.), compliance, and non-elastic resistance were made with the subject seated. Lung volume subdivisions, M.V.V., and the ventilation volumes were expressed at B.T.P.S. Age was recorded to the nearest year, height with the subject in socks, weight with light clothing.

\section{Results}

In Table 2 the physical characteristics of the individuals studied are shown, and in Tables 3 and 4 the results of the physiological tests are presented. In order to check the validity of the sample, the results obtained in the present series are compared with those obtained in this laboratory previously on a similar group of miners between 41 and 50 years of age (Zwi and Becklake, 1958). The previous group was selected at random from the Bureau records on the basis of age and a normal chest radiograph. It is of interest to note that the mean age of the previous group was 45 years, and that of the present group is
44 , although the age range of the present group is 41 to 45 years. Mean values for the individual tests and lung function scores in the two series are remarkably similar. (Using Student's t test there were no significant differences between the two series at the $5 \%$ level.)

The data were next examined to see if it could be shown that either grade of dyspnoea (a subjective measure of pulmonary performance) or any physiological tests (measuring function objectively) showed a relationship with estimated dust exposure.

It will be seen in Table 5 that neither grade of dyspnoea, nor the physiological test score, nor any of the tests done at rest could be shown to correlate significantly with dust exposure estimated either as particle-hours or as shifts on rock breaking. However, a negative correlation was observed between both estimates of dust exposure and the two tests of effort, i.e., ventilation equivalent for $\mathrm{O}_{2}$ during effort requiring 1 litre of $\mathrm{O}_{2}$ per minute, and exercise ventilation at a standardized effort of $350 \mathrm{~kg} .-\mathrm{m}$. per minute. These relationships imply that for a particular grade of effort the ventilation was lower in the men with the most dust exposure, the reverse in fact of what had been expected. Scrutiny of the full battery of test results in each individual makes the possibility that lower ventilation was due to abnormal lung function most unlikely.

It must be concluded, therefore, that neither grade of dyspnoea nor any of the objective measurements of lung function made in this study appeared to deteriorate in relation to the degree of dust exposure in radiologically normal miners in the present series. On the contrary, exercise capacity appeared best in those men whose estimated dust exposure was the greatest.

The results were examined from the point of view of the grade of dyspnoea to see whether those miners with breathlessness had any common factor to suggest the cause of their complaint. From Table 5 it will be seen that grade of dyspnoea correlated with certain tests of lung function, namely measurements of airflow (M.V.V. and M.M.F.), of adaptation to exercise (ventilation equivalent for $\mathrm{O}_{2}$ and exercise ventilation), and the dyspnoeic index. It should be

TABLE 2

PHYSICAL CHARACTERISTICS, MINING SERVICE, AND LUNG FUNCTION SCORE OF MEN STUDIED IN BOTH SERIES

\begin{tabular}{|c|c|c|c|c|c|c|c|c|}
\hline & $\begin{array}{l}\text { No. of } \\
\text { Cases }\end{array}$ & $\begin{array}{c}\text { Age } \\
\text { (years) }\end{array}$ & $\underset{(\mathrm{cm} .)}{\text { Height }}$ & $\begin{array}{l}\text { Weight } \\
\text { (kg.) }\end{array}$ & $\begin{array}{c}\text { Surface } \\
\text { Area } \\
\text { (sq. m.) }\end{array}$ & $\begin{array}{l}\text { Total } \\
\text { Mining } \\
\text { Service } \\
\text { (years) }\end{array}$ & $\begin{array}{l}\text { Rock- } \\
\text { breaking } \\
\text { Service } \\
\text { (years) }\end{array}$ & $\begin{array}{l}\text { Lui:g } \\
\text { Function } \\
\text { Score }\end{array}$ \\
\hline $\begin{array}{l}\text { Present series } \\
\text { Standard deviation } \\
\text { Previous series } \\
\text { Standard deviation }\end{array}$ & $\begin{array}{l}34 \\
10\end{array}$ & $\begin{array}{c}44 \cdot 0 \\
1 \cdot 26 \\
45 \cdot 0 \\
2 \cdot 21\end{array}$ & $\begin{array}{c}176 \cdot 1 \\
6 \cdot 27 \\
175 \cdot 6 \\
5 \cdot 80\end{array}$ & $\begin{array}{l}79 \cdot 9 \\
10 \cdot 25 \\
78 \cdot 5 \\
11 \cdot 40\end{array}$ & $\begin{array}{l}1.961 \\
0 \cdot 1381 \\
1.936 \\
0 \cdot 1637\end{array}$ & $\begin{array}{c}18 \cdot 27 \\
2 \cdot 439 \\
17 \cdot 00 \\
3 \cdot 070\end{array}$ & $\begin{array}{c}11 \cdot 15 \\
6 \cdot 031 \\
4 \cdot 60 \\
5 \cdot 770\end{array}$ & $\begin{array}{c}-10.86 \\
5.071 \\
-10.06 \\
2.460\end{array}$ \\
\hline
\end{tabular}


TABLE 3

LUNG VOLUME MEASUREMENTS, MIXING, AND EXERCISE VENTILATION IN PRESENT SERIES AND IN A PREVIOUS COMPARABLE SERIES

\begin{tabular}{|c|c|c|c|c|c|c|c|c|c|c|c|c|}
\hline & $\begin{array}{c}\text { Vital } \\
\text { Capacity }\end{array}$ & $\begin{array}{l}\text { Residual } \\
\text { Volume }\end{array}$ & $\begin{array}{c}\text { Total } \\
\text { Lung }\end{array}$ & $\begin{array}{c}\text { Func- } \\
\text { tional } \\
\text { Residual }\end{array}$ & R.V. & F.R.C. & \begin{tabular}{|c|} 
Mixing \\
Index of \\
Becklake \\
and
\end{tabular} & Oxim & netry & $\begin{array}{l}\text { Ven } \\
\text { Equ } \\
\text { for } \\
(1 . / \\
\mathrm{O}_{2} \mathrm{u}\end{array}$ & $\begin{array}{l}\text { ilation } \\
\text { ivalent } \\
\text { ixygen } \\
\text { 00ml. } \\
\text { ptake) }\end{array}$ & $\begin{array}{c}\text { Exercise } \\
\text { Venti- }\end{array}$ \\
\hline & in Litres & in Litres & $\begin{array}{l}\text { (T.L.C.) } \\
\text { in Litres }\end{array}$ & in Litres & T.L.C. & T.L.C. & $\begin{array}{l}\text { (1954) } \\
\text { (1./litre } \\
\text { F.R.C.) }\end{array}$ & $\begin{array}{c}\text { Maximum } \\
\text { Fall on } \\
\text { Effort } \\
(\%)\end{array}$ & $\begin{array}{c}\text { Maximum } \\
\text { Rise on } \\
\text { Oxygen } \\
(\%)\end{array}$ & $\underset{\text { Rest }}{\text { At }}$ & $\begin{array}{c}\text { On Effort } \\
\text { Requir- } \\
\text { ing } \\
11.0_{2} / \mathrm{min} .\end{array}$ & (i./min.) \\
\hline $\begin{array}{l}\text { Present } \\
\text { series }\end{array}$ & $4 \cdot 81$ & 1.94 & $6 \cdot 76$ & $3 \cdot 26$ & $28 \cdot 5$ & $48 \cdot 4$ & 3.42 & -0.60 & +6.74 & 3.62 & $2 \cdot 93$ & $36 \cdot 5$ \\
\hline $\begin{array}{l}\text { Standard } \\
\text { deviation } \\
\text { Previous }\end{array}$ & 0.627 & 0.637 & 0.677 & 0.812 & $7 \cdot 32$ & $8 \cdot 64$ & $0.75)$ & $1 \cdot 167$ & 1.635 & $1 \cdot 019$ & 0.410 & $4 \cdot 28$ \\
\hline series & $4 \cdot 83$ & 1.93 & $6 \cdot 81$ & $3 \cdot 51$ & $28 \cdot 2$ & $51 \cdot 6$ & $3 \cdot 33$ & $1 \cdot 34$ & $+6 \cdot 33$ & $4 \cdot 35$ & 2.99 & \\
\hline deviation & 0.753 & 0.507 & 0.980 & 0.737 & $5 \cdot 75$ & 8.97 & 0.558 & $1.77 J$ & $1 \cdot 380$ & 1.420 & 0.560 & \\
\hline
\end{tabular}

*Hugh-Jones and Lambert (1952).

TABLE 4

WORK OF BREATHING STUDIES IN PRESENT SERIES AND IN A PREVIOUS COMPARABLE SERIES

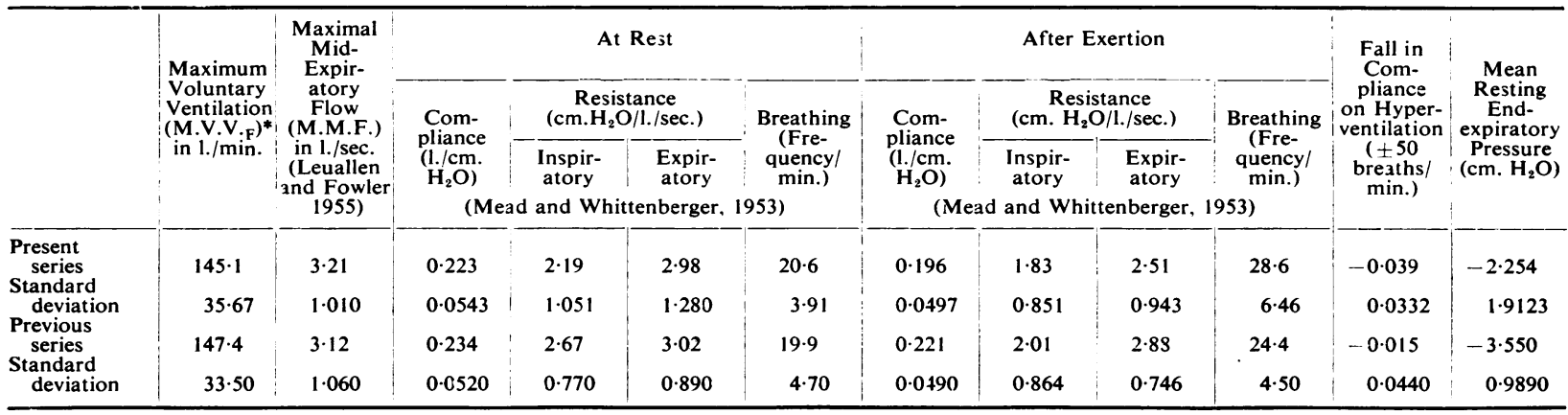

*Terminology recommended by Gandevia and Hugh-Jones (1957).

TABLE 5

CORRELATION COEFFICIENTS OF GRADE OF DYSPNOEA AND ESTIMATED DUST EXPOSURE WITH LUNG FUNCTION SCORE, LUNG FUNCTION TESTS, AND SMOKING

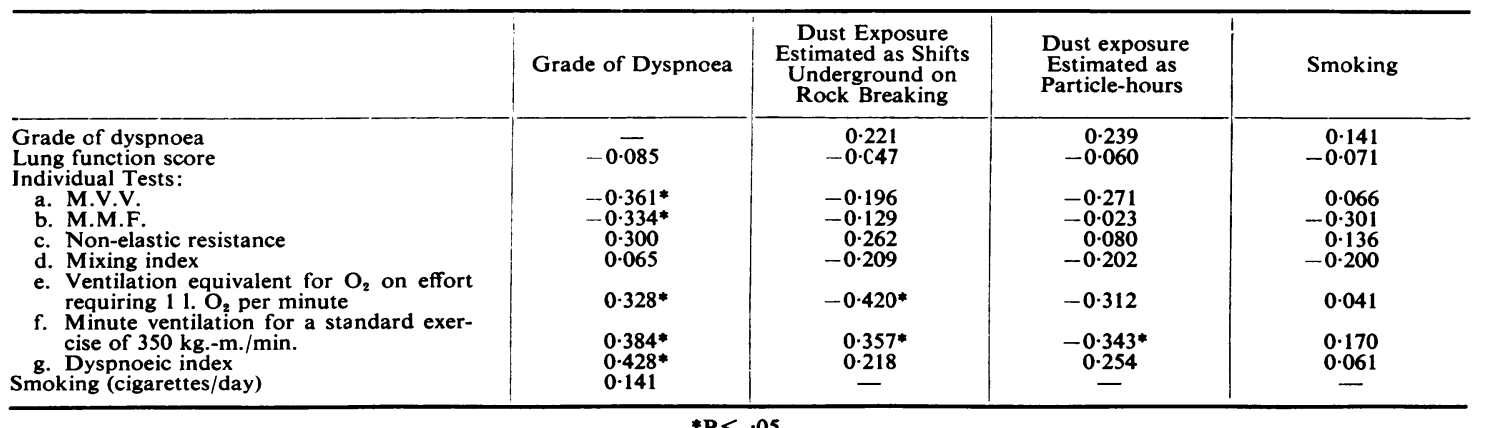

noted that, although these correlations are statistically significant, they are not high. Further, the number of men in whom rhonchi had been found on five or more occasions at the annual routine examination was higher (four out of seven) in the group with grade 3 dyspnoea than in the group with no complaint of dyspnoea (three out of 15), as was the incidence of cough and sputum (Tables 6 and 7). 
TABLE 6

DUST EXPOSURE AND LUNG FUNCTION TESTS IN MINERS GROUPED ACCORDING TO GRADE OF DYSPNOEA

\begin{tabular}{|c|c|c|c|c|c|c|c|c|}
\hline & $\begin{array}{c}\text { No. of } \\
\text { Subjects }\end{array}$ & $\begin{array}{c}\text { Shifts } \\
\text { Worked on } \\
\text { Rock } \\
\text { Breaking }\end{array}$ & $\begin{array}{l}\text { Dust } \\
\text { Exposure } \\
\text { (particle- } \\
\text { hours in } \\
\text { millions) }\end{array}$ & $\begin{array}{c}\text { Smoking } \\
\text { Habits } \\
\text { (cigarettes/ } \\
\text { day) }\end{array}$ & $\begin{array}{l}\text { Lung } \\
\text { Function } \\
\text { Score }\end{array}$ & $\begin{array}{c}\text { Dyspnoeic } \\
\text { Index } \\
(\%)\end{array}$ & $\begin{array}{l}\text { M.V.V./min.) } \\
\text { (I./ming }\end{array}$ & $\begin{array}{l}\text { M.M.F. } \\
\text { (1./sec.) }\end{array}$ \\
\hline $\begin{array}{l}\text { Men with no dyspnoea } \\
\text { (Grade 1) } \\
\text { Standard deviation } \\
\text { Men with Grade } 2 \text { dyspnoea } \\
\text { Standard deviation } \\
\text { Men with Grade } 3 \text { dyspnoea } \\
\text { Standard deviation }\end{array}$ & $\begin{array}{r}15 \\
12 \\
7\end{array}$ & $\begin{array}{l}2371 \cdot 4 \\
1761 \cdot 20 \\
3168 \cdot 4 \\
1817 \cdot 06 \\
3240 \cdot 1 \\
1396 \cdot 48\end{array}$ & $\begin{array}{l}4 \cdot 11 \\
1 \cdot 214 \\
4 \cdot 56 \\
1 \cdot 056 \\
4 \cdot 76 \\
0 \cdot 960\end{array}$ & $\begin{array}{l}23 \cdot 3 \\
17 \cdot 99 \\
15 \cdot 0 \\
11 \cdot 68 \\
32 \cdot 9 \\
13 \cdot 80\end{array}$ & $\begin{array}{c}-10 \cdot 55 \\
4 \cdot 386 \\
-12 \cdot 58 \\
5 \cdot 833 \\
-8 \cdot 60 \\
4 \cdot 699\end{array}$ & $\begin{array}{c}24 \cdot 1 \\
4 \cdot 60 \\
30 \cdot 3 \\
11 \cdot 99 \\
34 \cdot 5 \\
9 \cdot 61\end{array}$ & $\begin{array}{c}158 \cdot 3 \\
34 \cdot 69 \\
139 \cdot 8 \\
36 \cdot 42 \\
126 \cdot 0 \\
28 \cdot 95\end{array}$ & $\begin{array}{l}3 \cdot 44 \\
0 \cdot 902 \\
3 \cdot 34 \\
1 \cdot 073 \\
2 \cdot 47 \\
0 \cdot 879\end{array}$ \\
\hline
\end{tabular}

TABLE 7

INCIDENCE OF CLINICAL FEATURES IN MINERS GROUPED ACCORDING TO GRADE OF DYSPNOEA*

\begin{tabular}{|c|c|c|c|c|c|}
\hline & $\begin{array}{l}\text { No. of } \\
\text { Subjects }\end{array}$ & $\begin{array}{l}\text { Rhonchi Heard } \\
\text { on Five or More } \\
\text { Periodical } \\
\text { Examinations }\end{array}$ & Cough & Sputum & $\begin{array}{l}\text { History of Chest } \\
\text { Illness in Past } \\
\text { Three Years }\end{array}$ \\
\hline
\end{tabular}

*The figures in parenthesis denote the percentage of cases in each group with a particular characteristic.

The grade of dyspnoea was not significantly related to smoking whether compared alone or combined with dust exposure (the multiple correlation coefficients were $\mathbf{0 . 2 9 7}$ against smoking plus rock-breaking shifts, and 0.303 against smoking plus particle-hours). Smoking alone did not correlate significantly with lung function tests in this series (Table 5), but the smokers had a lower M.V.V. and M.M.F. than the non-smokers (including exsmokers, all of whom had not smoked for 10 or more years). The mean M.V.V. and M.M.F. of the eight non-smokers was $157 \mathrm{l} . / \mathrm{min}$. and 3.58 1./sec. respectively, whereas that of the 26 smokers was $142 \mathrm{l} . / \mathrm{min}$. and $3.09 \mathrm{l} / \mathrm{sec}$. These results are similar to those of Higgins (1959), but unlike this author we found no differences in the incidence of bronchitic chest illness, cough, sputum, and wheezing in smokers and non-smokers. However, rhonchi were not recorded in any of the latter, but in six of the former group.

\section{Discussion}

In this study of Rand miners without radiological signs of silicosis, no correlation could be demonstrated between degree of breathlessness or physiological tests on the one hand and estimated dust exposure on the other. In so far as the degree of silicosis has been shown to relate to dust exposure in Rand gold-miners (Hatch, 1955; du Toit, 1958), the present findings do not point to early silicosis (as yet radiologically undetectable) as the cause of symptoms in these miners. Is there any evidence to suggest other causes?
Our results indicate a physiological rather than a psychological basis for the symptoms. The grade of dyspnoea was shown to correlate with the extent of deterioration in exercise tolerance (as measured by the ventilation equivalent on effort, or by ventilation at a standard work load). Furthermore, subjective assessment of disability correlated with ventilatory impairment as judged by the M.V.V. and M.M.F. values and the dyspnoeic index (Table 5). Although psychological factors, such as lack of motivation, might lead to both exaggeration of symptoms and poor M.V.V. values in the same subject, it is unlikely that hyperventilation on steady effort could be attributed to the same cause.

On the other hand, these test results would not be inconsistent with the presence of chronic bronchitis as the likely cause of symptoms, a possibility which is suggested by the high incidence of cough and sputum in the more dyspnoeic subjects and the frequent detection of rhonchi at annual clinical examinations (Table 7).

Conclusions should be drawn from these observations with caution. The series tested has been small and only $75 \%$ of the men sampled were investigated.' However, there is strong support for the validity of the sample in that the results agreed well with the previous series studied. It cannot be deduced that the absence of correlation between dust exposure and subjective and objective estimates of pulmonary disability is conclusive evidence that dust exposure is not the cause of the disability in the men studied. It is not impossible that the very fact of a miner being able to continue rock breaking 
over long periods means he is physically very fit and that selection of men with longer rock-breaking service is thus also selection of the fitter subjects. Thus the miners with longest service might initially have had "super-normal" test values compared with which their present values might in fact represent deterioration of function. The negative correlation between ventilation on standard effort and degree of exposure would be consistent with this view.

Neither can it be concluded that the absence of correlation of dyspnoea with estimated dust exposure excludes other mining stresses such as exposure to fumes, or changes in temperature, humidity, and barometric pressure as possible aetiological factors. These factors, if important aetiologically, might result in a correlation between disability and total underground service, a possibility which could not be tested in this study due to the nature of selection of subjects, all of whom had similar periods of total service.

However, if these reservations are borne in mind, this study suggests, as an hypothesis worthy of further testing, that in Rand gold-miners with no radiological evidence of silicosis, disability when present may be the result of chronic bronchitis rather than of early silicosis or psychological factors. Whether such bronchitis is attributable to mining or might have developed in the same individuals had they been otherwise employed, remains to be ascertained. In Britain a relationship between bronchitis and smoking has been demonstrated (Oswald and Medvei, 1955; Higgins, 1959), but in Rand miners there is not yet any conclusive evidence on this point.

In so far as the present study provided no evidence to suggest that disability related to dust exposure in the Rand gold-miner who is free of radiological silicosis, it is in agreement with the work of Newell and Browne (1955) on British coalworkers. Their investigation, covering men between the ages of 15 and 65 with chest radiographs varying from normal to massive fibrosis, examined the significance of dust exposure (measured in years of service on the coalface) in a much wider context. They reached the conclusion that, although proportionately more faceworkers have symptoms than other colliery employees, the proportion with symptoms is not related to the number of years of work on the coalface for men of the same age.

Higgins, Oldham, Cochrane, and Gilson (1956), reporting on Lancashire coal-miners, found no clear relation between bronchitis and dust exposure. Worth, Valentin, Gasthaus, Hoffmann, and Venrath (1955) could find no acute disturbance of respiratory function in 30 coal-miners in the lower Rhine region, after seven and a half hours of underground work in a dusty atmosphere, either clinically, spirographically, or by blood analysis. Our findings support these reports in that they are consistent with the presence of bronchitis as a cause of symptoms in the miner who is free of radiological silicosis, but symptoms do not appear to relate to the degree of dust exposure. However, it is probably not valid to make direct comparison of our results on Rand gold-miners with the results of studies on British and Rhineland coal-miners, since dust concentrations in the latter areas are higher, the size distribution of the dust is coarser, and the mineral composition is different. Also other occupational stresses of mining differ in various countries. These factors are probably of importance in explaining the differences between the studies already referred to and a number of others in the literature which stress the association of dust and bronchitis diagnosed clinically (Dautrebande, 1952, quoted by Higgins and others, 1956) and the acute depressant effects on lung function in normal subjects which follow the inhalation of dust (Dautrebande, Alfrod, Highman, Downing, and Weaver, 1948; DuBois, Alcala, and Dautrebande, 1958). The conflicting nature of views expressed suggests that many other variables may be influencing the response of an individual to dust inhalation.

It is important also to stress that in studies in which dust exposure is assessed retrospectively over many years, the inherent inaccuracies place a severe limit on the validity of the conclusions. To provide a clear-cut answer to the effect of dust exposure on pulmonary function, prospective studies are required in which dust exposure is accurately recorded and pulmonary function is assessed at regular time intervals.

This work was done while the authors were on the staff of the Pneumoconiosis Research Unit of the Council for Scientific and and Industrial Research.

The authors wish to acknowledge the generous assistance of the Transvaal and Orange Free State Chamber of Mines and the Union of South Africa Government Department of Mines, who arranged for the miners selected to be studied, and to the former for access to the service records of the miners in this investigation. They would also like to thank Dr. A. J. Orenstein, Director of the Pneumoconiosis Research Unit, for his interest and support in this study, and Dr. J. H. Loots, Director of the Pneumoconiosis Bureau, for making available the material for this investigation.

Physiological tests were carried out by Messrs. L. du Preez, I. P. Olivier, and J. J. Hefer, and Miss C. B. Bruyns, for whose assistance the authors are most grateful. They also wish to thank Mrs. U. MacMahon who was responsible for the considerable administrative arrangements necessary, and Dr. M. McGregor for help in the preparation of the text. 


\section{REFERENCES}

Becklake, M. R., and Goldman H. I. (1954). S. Afr. J. med. Sci.,

—, 19, 21 . 400.

Dautrebande, L. (1952). Quoted by Higgins and others (1956).

Alfrod, W. C., Highman, B., Downing, R., and Weaver, F. L. (1948). J. appl. Physiol., 1, 339.

Doll, R., and Hill, A. B. (1950). Brit. med. J., $2,739$.

DuBois, A. B., Alcala, R., Jr., and Dautreband, L. (1958). Fed. Proc., 17, 38

du Toit, R.'S. J. (1958). Thesis submitted to the University of the Witwatersrand.

Fletcher, C. M. (1952). Proc. roy. Soc. Med., 45, 577.

Gandevia, B., and Hugh-Jones, P. (1957). Thorax, 12, 290
Hatch, T. (1955). Amer. industr. Hyg. Ass. Quart., 16, 30.

Higgins, I. T. T. (1959). Brit. med. J., 1, 325.

-, Oldham, P. D., Cochrane, A. L., and Gilson, J. C. (1956) Ibid., 2, 904.

Hugh-Jones, P., and Lambert, A. V. (1952). Ibid., 1, 65.

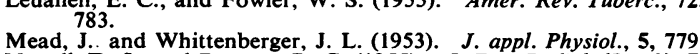

Newell, D. J., and Browne, R. C. (1955). J. Fac. Radiol. (Lond.), 7,

Oswald, N. C., and Medvei, V. C. (1955): Lancet, 2, 843.

Pemberton, J. (1956). A.M.A. Arch. industr. Hlth, 13, 529.

Worth, G. Valentin, H., Gasthaus, L., Hoffmann, H., and Venrath

H. (1955). Arch. Gewerbepath. Gewerbehyg., 14, 37 Zwi, S., and Becklake, M. R. (1958). Brit. J. industr. Med., 15 ,

\section{THE JULY (1959) ISSUE}

The July (1959) issue contains the following papers :-

Occupational Lung Cancer: A Review. By Richard Doll.

Biochemical Studies on the Toxicity of Tetraethyl Lead and Other Organo-lead Compounds. By Jill E. Cremer.

Dermatitis in the South Wales Mining Industry: A Report of a Survey of Two Collieries. By Bryan F. Matthews.

Accidents in a Naval Dockyard. By C. P. Collins.

The Acute Toxic Effects of Black Smoke. By R. E. Pattle, G. D. Wedd, and F. Burgess.

Some Hazards in the Manufacture and Use of Plastics. By D. Kenwin Harris.

Patterns of Sickness Absence in a Railway Population. By Cecil Gordon, A. R. Emerson, and Derek S. Pugh.

The Action Exerted by Certain Pneumoconiotic Factors upon the Acid Mucopolysaccharide Contents of Pulmonary

Macrophages. By N. Gh. Lupu, Doina Velican, C. Velican, and V. Olinescu.

Miscellanea:

A Case of Cirrhosis and Primary Carcinoma of the Liver in Chronic Industrial Arsenical Intoxication. By S. S. Jhaveri.

Book Reviews.

A number of copies are still available and may be obtained from the Publishing Manager, British Medical Association, Tavistock Square, W.C.1, price 17s. $6 d$. 